\title{
Efek Latihan Fisik Terhadap Remodeling Jantung
}

\author{
Rita Hamdani ${ }^{1}$, Finesa A Hasye ${ }^{2}$
}

\begin{abstract}
Abstrak
Latihan fisik sangat bermanfaat bagi individu yang sehat maupun yang memiliki resiko untuk terjadinya Penyakit Kardio Vaskular (PKV). Latihan fisik teratur menurunkan risiko PKV dengan cara: mengurangi trigliserida, meningkatkan kolesterol HDL, menurunkan tekanan darah, meningkatkan metabolisme glukosa serta sensitivitas insulin, mengurangi berat badan dan mengurangi respon inflamasi. Pada dasarnya ada dua cara untuk membedakan antara hipertrofi jantung fisiologis dan patologis: remodeling LV patologis disertai dengan disfungsi LV (baik diastolik, sistolik, atau keduanya) dan meningkatnya ketidakseimbangan antara massa otot dengan angiogenesis, sedangkan remodeling LV fisiologis meningkatkan fungsi ventrikel dan terdapat keseimbangan antara pertumbuhan massa otot dan angiogenesis. Hipertrofi jantung fisologis memberikan efek kardioprotektif dan tidak terkait dengan gagal jantung. Sedangkan hipertrofi patologis dikaitkan dengan keparahan penyakit kardiovaskular yang menyebabkan peningkatan risiko gagal jantung, aritmia dan berakhir kematian.
\end{abstract}

Kata kunci: latihan fisik, remodeling jantung, hipertrofi fisiologis

\begin{abstract}
Exercise is beneficial for healthy individuals as well as those who are at risk for Cardio Vascular Disease (CVD). Regular physical exercise reduces CVD risk by increasing HDL cholesterol and reducing triglycerides, lowering blood pressure, improving glucose metabolism and insulin sensitivity, lose body weight, and inhibit inflammatory responses. There are two ways to distinguish between pathological and physiological hypertrophy: pathological LV remodeling accompanied by $L V$ dysfunction (either diastolic, systolic, or both) and increased imbalance between muscle mass and angiogenesis, whereas physiological LV remodeling improves ventricular function and there is a balance between growth of muscle mass and angiogenesis. Physiological hypertrophy provides cardioprotective effect and not associated with heart failure. While pathological hypertrophy is associated with the severity of cardiovascular disease that leads to increased risk of heart failure, arrhythmias and death.
\end{abstract}

Keywords: exercise, cardiac remodeling, physiological hypertrophy

Affiliasi penulis: 1. Bagian Kardiologi dan Kedokteran Vaskular FK Unand, 2. Program Pendidikan Dokter Spesialis-1 IImu Penyakit Jantung dan Pembuluh Darah FK Unand

Korespondensi: Rita Hamdani, Email: r_dani82@yahoo.com

\section{PENDAHULUAN}

Latihan fisik adalah aktifitas yang dilakukan secara terencana, terstruktur, berulang dan bertujuan meningkatkan atau menjaga kesehatan. Latihan fisik sangat bermanfaat bagi individu yang sehat maupun yang memiliki resiko untuk terjadinya penyakit kardiovaskular (PKV). Latihan fisik menginduksi efek sistemik yang positif untuk mengontrol metabolisme, otot rangka, fungsi kognitif, dan fungsi kardiovaskular yang bergantung pada jenis, intensitas dan durasi latihan. ${ }^{1,2}$

Rangkaian adaptasi pada miokard secara kolektif disebut sebagai "jantung atlet" dan termasuk peningkatan massa jantung, formasi pembuluh darah baru dan penurunan kadar kolagen. Individu dengan tingkat aktivitas fisik yang tinggi memiliki prevalensi yang lebih rendah dan tingkat kematian yang lebih rendah terhadap kejadian PKV. Jadi latihan fisik telah dilakukan tidak hanya sebagai cara untuk mempertahankan gaya hidup sehat tapi juga sebagai resep nonfarmakologis yang penting dan aman untuk pencegahan dan pengobatan PKV., 
Latihan fisik teratur menurunkan risiko PKV dengan mengurangi trigliserida dan meningkatkan kolesterol HDL, menurunkan tekanan darah, meningkatkan metabolisme glukosa dan sensitivitas insulin, mengurangi berat badan, dan mengurangi respon inflamasi. Perbaikan faktor risiko ini mengurangi 59\% kejadian PKV, sedangkan sisanya $41 \%$ dapat dihasilkan dari peningkatan fungsi endotel, peningkatan tonus vagal sehingga mengurangi denyut jantung, remodeling vaskular termasuk diameter pembuluh darah yang lebih besar dan meningkatkan bioavailabilitas nitrat oksida. ${ }^{3}$

Hipertrofi jantung patologis dikaitkan dengan prognosis yang buruk dan merupakan ciri khas gagal jantung. Sebaliknya, latihan fisik yang meyebabkan hipertrofi jantung fisiologis memberikan efek kardioprotektif. Latihan fisik digambarkan sebagai kemampuan melawan perubahan struktural dan fungsional jantung terhadap PKV dengan berkontribusi terhadap perubahan fenotip patologis ke hipertrofi jantung fisiologis. Terdapat bukti kuat yang menghubungkan antara latihan fisik dengan penurunan risiko PKV, banyak mekanisme yang belum diketahui secara pasti. Saat ini, perhatian lebih diberikan pada mekanisme seluler dan molekuler dalam usaha untuk membedakan antara patologis dan fisiologis hipertrofi jantung. ${ }^{4}$

Tinjauan pustaka ini bertujuan untuk menjelaskan efek latihan fisik terhadap remodeling jantung.

ISI

\section{Latihan Fisik}

Latihan fisik adalah aktifitas yang dilakukan secara terencana, terstruktur, berulang dan bertujuan meningkatkan atau menjaga kesehatan. Latihan fisik yang terutama membutuhkan peningkatan transportasi oksigen disebut sebagai latihan aerobik, sedangkan latihan fisik yang menekankan pada sistem muskoloskeletal disebut sebagai latihan kekuatan atau ketahanan. $^{2}$

Latihan fisik meningkatkan kebutuhan oksigen, yang mendorong sistem kardiovaskular untuk meningkatkan curah jantung dan perbedaan oksigen arteri-vena. Kenaikan curah jantung ditambah dengan energi yang dibutuhkan seperti peningkatan satu liter konsumsi oksigen (VO2) menghasilkan kenaikan 5 sampai 6 liter curah jantung. Curah jantung ditingkatkan dengan menaikkan baik laju jantung maupun stroke volume (SV). Beberapa mekanisme meningkatkan perbedaan oksigen arteri-vena, termasuk hemokonsentrasi akibat hilangnya cairan plasma ke dalam ruang ekstravaskular sebagai akibat dari tekanan osmotik yang dihasilkan oleh metabolit yang dilepaskan ke ruang interstisial selama aktifitas fisik, dan peningkatan ekstraksi oksigen arterial skeletal aktif dan otot jantung. Kebutuhan oksigen miokard sebagian bergantung pada laju jantung dan tekanan darah sistolik dan meningkat bila aktifitas fisik karena terjadi peningkatan baik laju jantung dan juga tekanan darah sistolik. ${ }^{2}$

Perbedaan tipe latihan fisik memberikan beban yang berbeda pada sistem kardiovaskular. Terdapat tiga tipe latihan fisik: ${ }^{1,5}$

1. Latihan isotonik (dinamis) didefinisikan sebagai kontraksi dari kelompok otot-otot besar yang menghasilkan gerakan, yang menginduksi beban volume kepada jantung. Pada latihan ini terjadi peningkatan signifikan pada curah jantung dan VO2 dan penurunan resistensi pembuluh darah sistemik. Hal ini dikaitkan dengan dilatasi ventrikel kiri dalam bentuk hipertrofi eksentrik.

2. Latihan isometrik (statis) didefinisikan sebagai kontraksi yang konstan dari kelompok otot-otot yang lebih kecil tanpa menghasilkan gerakan. Latihan ini menginduksi beban tekanan pada jantung. Latihan ini meningkatkan resistensi pembuluh darah sistemik dan menghasilkan curah jantung dan VO2 yang minimal. Hal ini dikaitkan dengan penebalan dinding dalam bentuk hipertrofi konsentris.

3. Latihan ketahanan. Latihan ini merupakan kombinasi antara isometrik dan isotonik dengan menggunakan kontraksi otot yang menghasilkan gerakan, seperti angkat beban.

Penurunan risiko kardiovaskular pada subjek yang paling aktif dibandingkan yang paling tidak aktif adalah sekitar $30 \%$. Pasien yang menjalani program rehabilitasi jantung menurunkan risiko penyakit jantung berulang. Mekanisme spesifik yang menimbulkan efek ini belum jelas, namun aktivitas fisik yang rutin memberikan banyak manfaat bagi individu 
yang beresiko terjadinya proses aterosklerosis. Secara khusus, aktifitas fisik rutin menurunkan tekanan darah sistolik, berat badan, glukosa darah, dan trigliserida dan meningkatkan kolesterol HDL. Beberapa efek latihan fisik di antaranya pada tekanan darah, glukosa, dan trigliserida terjadi cepat dalam waktu 24 jam setelah satu sesi latihan fisik. Latihan fisik juga memberikan efek baik pada faktor pembekuan dan inflamasi. Penigkatan tonus vagal dapat mengurangi risiko fibrilasi ventrikel sebagai respons terhadap iskemia. $^{2,4}$

\section{Remodeling Jantung}

Istilah "remodeling" digunakan untuk pertama kalinya pada tahun 1982 oleh Hockman dan Buckey, pada sebuah kasus infark miokard (MI). Istilah ini ditujukan untuk mengkarakterisasi penggantian jaringan infark dengan jaringan parut. Pada tahun 2000, sebuah konsensus dari forum internasional tentang remodeling jantung mendefinisikan remodeling jantung sebagai perubahan molekul, seluler dan interstisial yang secara klinis bermanifestasi pada perubahan ukuran, bentuk dan fungsi jantung yang diakibatkan cedera jantung. ${ }^{6}$

Proses awal remodeling jantung dipengaruhi oleh stimulus hemodinamik dari kelebihan beban transien, seperti apa yang terjadi dalam latihan fisik atau kelebihan beban persisten yang timbul dari kejadian seperti infark miokard atau dari beberapa penyakit seperti hipertensi (Gambar 1$)^{7}$

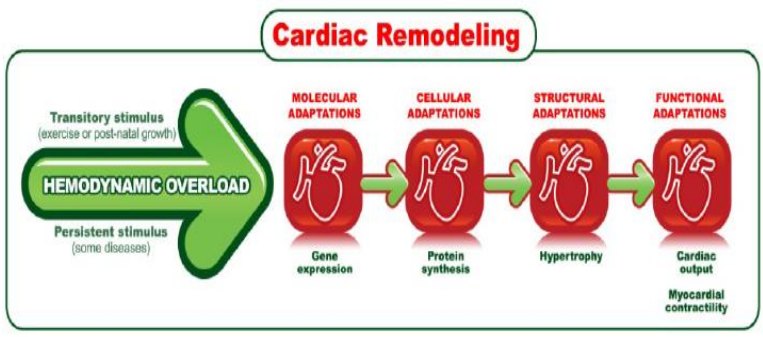

Gambar 1. Tahapan remodeling jantung ${ }^{8}$

Latihan fisik menyebabkan hipertrofi fisiologis, ditandai dengan tidak adanya fibrosis. Hal ini menunjukkan hipertrofi fisiologis yang disebabkan oleh latihan fisik lebih bergantung pada transkrip mRNA untuk sintesis protein, dan pemeliharaan sintesis protein. ${ }^{8}$
Diagnosis klinis remodeling didasarkan pada perubahan morfologi, perubahan pada diameter rongga, massa (hipertrofi dan atrofi), geometri (ketebalan dan bentuk dinding jantung), daerah parut setelah infark miokard, fibrosis dan infiltrasi inflamasi (misalnya di miokarditis). Metode yang paling sering digunakan untuk mendeteksi perubahan ini dengan ekokardiografi, ventrikulografi dan MRI. Metode diagnostik lain masih belum digunakan secara rutin, terdiri dari deteksi sel marker. Beberapa sel marker mengindikasikan proses remodeling, termasuk perubahan ekspresi myosin isoform rantai berat, dengan peningkatan alpha dan penurunan rantai berat beta-myosin, meningkatnya ekspresi GLUT-1, alphaactin, natriuretic peptide, galectin, caveolin, sintase neuronal nitrat oksida, angiotensin-converting enzyme, penurunan GLUT-4, SERCA2a dan oksidasi glukosa ke asam lemak. ${ }^{9}$

\section{Komponen dari Remodeling Jantung}

1. Miosit jantung

Miosit diyakini terlibat dalam proses remodeling. Miosit mendapat banyak perhatian mengenai aktivitas kontraktilnya dan kontribusi terhadap massa jantung. Jumlah miosit menurun dan menjadi panjang atau hipertrofi sebagai bagian dari proses kompensasi awal untuk menjaga stroke volume setelah hilangnya jaringan kontraktil. Ketebalan dinding ventrikel juga meningkat. Perubahan kondisi menjadikan peregangan membran sel sehingga menginduksi ekspresi gen terkait hipertrofi. Hal ini dapat menyebabkan sintesis protein kontraktil dan sarkomer baru. Peningkatan tekanan dinding jantung dapat memicu ketidakseimbangan energi dan iskemia, yang merupakan salah satu faktor penentu utama kebutuhan oksigen miokard. ${ }^{10}$

\section{Proliferasi fibroblas}

Baik fibroblas dan sel endotel aktif sebagai respons terhadap iskemik. Pada manusia dan hewan, stimulasi fibroblas meningkatkan sintesis kolagen dan menyebabkan fibrosis pada daerah infark dan non infark dari ventrikel, yang berkontribusi terhadap remodeling. ${ }^{10}$ 


\section{Degradasi kolagen}

Miokardium terdiri dari miosit dan didukung oleh jaringan penghubung yang terdiri dari kolagen fibrilar, yang disintesis dan terdegradasi oleh fibroblas interstisial. Kolagenase miokard dianggap sebagai proenzim penting yang muncul dalam bentuk inaktif di ventrikel. Aktivasi setelah cedera miokard berkontribusi terhadap peningkatan dimensi ruang sebagai respon terhadap besarnya tekanan. ${ }^{10}$

\section{Apoptosis}

Apoptosis merupakan regulasi penting terhadap kelebihan beban tekanan di mana apoptosis awal terjadi terkait dengan hipertrofi jantung. Pemicu lain apoptosis yang terkenal meliputi sitokin (terutama TNF-alfa dan interleukin), stres oksidatif dan kerusakan mitokondria. Bukti terbaru menunjukkan bahwa terjadi reproduksi miosit pada jantung dan meningkat pada saat cedera jantung. ${ }^{10}$

Remodeling Jantung yang disebabkan Latihan Fisik:

a. Ventrikel Kanan dan Sirkulasi Pulmonal

Selama latihan, peningkatan curah jantung ventrikel kiri menyebabkan peningkatan aliran balik ke atrium kanan. Pembesaran ventrikel kanan berkembang pada latihan ketahanan. Fungsi diastolik turut berubah, ditunjukkan oleh peningkatan aliran melintasi katup trikuspid. Kelebihan volume ini menyebabkan dilatasi dan penebalan otot atrium kanan dan ventrikel kanan. Efek latihan fisik terhadap ventrikel kanan hanya terlihat pada fase akut pasca latihan. Ventrikel kanan adalah ruang pertama yang menunjukkan adaptasi jantung atlet terutama pada fase pasca latihan selama latihan ketahanan. ${ }^{11}$

\section{b. Atrium Kanan}

Selama aktifitas fisik, terdapat kelebihan beban volume pada ruang jantung kanan. Latihan kekuatan menghasilkan kelebihan beban tekanan secara akut sedangkan kelebihan beban volume bersifat sementara, yang akan kembali normal saat istirahat. Sebaliknya, selama latihan ketahanan, kelebihan beban volume menyebabkan peningkatan dimensi atrium kanan secara akut yang menetap saat istirahat. Dilatasi atrium dan ventrikel kanan secara transien berkorelasi dengan pelepasan cardiac markers seperti
B-type natriuretic peptides dan troponin I, segera setelah latihan ketahanan berat seperti lari maraton. ${ }^{11}$

c. Atrium Kiri

Adaptasi atrium kiri tidak berdiri sendiri tapi selalu dikaitkan dengan pembesaran vetrikel kiri. Selama diastol, tekanan ventrikel kiri ditransmisikan kembali ke atrium kiri. Selama peningkatan tekanan pengisian diastol ventrikel kiri, tekanan atrium kiri meningkat untuk menghasilkan tekanan pengisian ventrikel kiri yang cukup. Mekanisme ini menentukan pembesaran atrium kiri dan peregangan pada miokardium atrium. ${ }^{11}$

d. Ventrikel Kiri

Latihan ketahanan akan menyebabkan kelebihan beban volume, sehingga terjadi peningkatan diastolic wall stress. Adaptasi ventrikel kiri untuk latihan ini adalah hipertrofi ventrikel eksentrik (peningkatan massa ventrikel dan dimensi rongga ventrikel). Sebaliknya, latihan kekuatan menentukan kelebihan tekanan dan peningkatan tekanan dinding sistolik. Dalam hal ini adaptasi ventrikel kiri adalah hipertrofi konsentris (peningkatan massa ventrikel dan ketebalan dinding dengan dimensi rongga normal). Keduanya menghasilkan massa ventrikel kiri yang meningkat. Pembesaran ventrikel kiri selalu sebanding dengan pembesaran bilik jantung lainnya. Adaptasi ruang jantung kanan dapat terlihat tepat setelah latihan fisik yang berkepanjangan, namun adaptasi ventrikel kiri terhadap latihan menjadi terlihat setelah masa latihan beberapa bulan. Adaptasi ini mengalami regresi setelah periode penghentian latihan sekitar 3 bulan. Setelah periode "de-conditioning" menunjukkan pengurangan ketebalan dinding septum sebesar 15$33 \%$, sedangkan pengurangan ketebalan kedua septal (sekitar 15\%) dan dimensi rongga ventrikel kiri (sekitar 7\%) dapat diamati setelah 1-13 tahun de-training. Hal ini menunjukkan bahwa rongga ventrikel kiri berkurang lebih lambat dan sedikit dibanding ketebalan dindingnya. ${ }^{11}$

Peningkatan jumlah massa jantung didefinisikan sebagai respon hipertrofik, ada dua bentuk yang sangat berbeda dari hipertrofi ventrikel, satu fisiologis dan lainnya patologis. Pada tingkat seluler, kedua proses hipertrofik berimplikasi pada adaptasi seperti peningkatan ukuran kardiomiosit, 
tingkat sintesis protein dan reorganisasi dari struktur sarkomer; ada banyak perbedaan yang membedakan mereka. Pertama, harus dibedakan secara struktural dan fungsional sebagai remodeling fisiologis atau patologis. Kedua, oleh rangsangan yang menginduksi hipertrofi, yaitu kelebihan tekanan atau kelebihan beban volume. ${ }^{4,12}$

Remodeling LV disebabkan oleh rangsangan fisiologis menyebabkan terpeliharanya atau bahkan meningkatkan fungsi LV, menurunkan kandungan kolagen, berkurangnya fibrosis, meningkatkan angiogenesis, memperbaiki kapasitas antioksidan miokard, dan menurunkan disfungsi mitokondria sehingga mencegah apoptosis kardiomiosit. Sebaliknya, hipertrofi patologis dikaitkan dengan keparahan penyakit kardiovaskular yang menyebabkan peningkatan risiko gagal jantung, aritmia dan berakhir kematian. Remodeling LV diinduksi oleh stress patologis yang menyebabkan penurunan curah jantung secara progresif, peningkatan apoptosis, perubahan metabolisme kardiomiosit dari asam lemak ke glukosa, dan peningkatan fibrosis. ${ }^{13,14}$

Secara keseluruhan, pada dasarnya ada dua cara untuk membedakan antara hipertrofi jantung fisiologis dan patologis: remodeling LV patologis disertai dengan disfungsi LV (baik diastolik, sistolik, atau keduanya) dan meningkatnya ketidakseimbangan antara massa otot dengan angiogenesis, sedangkan remodeling LV fisiologis meningkatkan fungsi ventrikel dan terdapat keseimbangan antara pertumbuhan massa otot dan angiogenesis. ${ }^{15}$

Pada latihan isotonik (misalnya, berenang, bersepeda, dan berlari), perubahan hemodinamik yang utama meningkatkan detak jantung dan stroke volume, yang merupakan komponen dari curah jantung. Sejalan dengan proses tersebut terjadi peningkatan efektivitas otot skeletal dan penurunan resistensi pembuluh darah perifer yang meningkatkan alirah balik ke jantung. Karena itu, kelebihan beban jantung terjadi beban volume, yang menyebabkan hipertrofi ventrikel kiri eksentrik. ${ }^{15}$

Pada latihan isometrik (misalnya angkat beban, gulat dan binaraga), kekuatan dikembangkan dengan sedikit gerakan. Baik otot rangka dan jantung beradaptasi sebagai respon terhadap jenis latihan ini.
Hasil latihan ketahanan menghasilkan perubahan hemodinamik yang ditandai dengan peningkatan tekanan darah yang menyebabkan kelebihan beban tekanan di jantung. ${ }^{15}$

Pada tingkat sel, hipertrofi konsentrik ditandai dengan panambahan paralel sarkomer baru dan pertumbuhan lateral dari kardiomiosit. Hipertrofi ini umumnya menyebabkan penebalan sel kardiomiosit sehingga terjadi penebalan dinding LV, baik penurunan diameter ruang LV (patologis) atau tidak ada perubahan pada diameter ruang LV (fisiologis). Hipertrofi eksentrik karena kelebihan beban volume ditandai dengan penambahan sarkomer secara seri yang menyebabkan peningkatan panjang sel miosit sehingga meningkatkan massa jantung dengan peningkatan volume ruang. Fenotipe remodeling khas berhubungan dengan dilatasi LV (patologis) atau peningkatan proporsi dilatasi LV dan ketebalan dinding LV (fisiologis)

e. Aorta

Selama latihan ketahanan, peningkatan volume stroke berulang dan terus menerus menyebabkan distensi dinding aorta. Latihan kekuatan ditandai dengan latihan intensitas tinggi yang cepat dan singkat meningkatkan curah jantung. Pada saat yang sama, aktivitas sistem saraf simpatik dan pembuluh darah membuat peningkatan denyut jantung dan resistensi perifer sistemik secara cepat. Beban hemodinamik selama latihan yang berkepanjangan dan kelebihan tekanan selama latihan kekuatan dapat menyebabkan dilatasi Aorta. ${ }^{11}$

\section{Mekanisme Molekuler Yang Berhubungan Dengan Latihan Fisik Dan Remodeling Jantung}

Mekanisme seluler dan molekuler sebagian besar telah dipelajari. Pemicu latihan fisik yang menginduksi remodeling termasuk peningkatan beban hemodinamik, peningkatan aktivitas simpatis, dan pelepasan hormon dan faktor pertumbuhan, semua yang mengaktifkan beberapa jalur molekuler. ${ }^{16}$

Latihan fisik mewakili stimulus yang dinamis dan intermiten terkait dengan meningkatnya aktifitas simpatis (pelepasan katekolamin: norepinephrine/ noradrenalin, epinefrin/adrenalin), stress mekanis, perubahan pelepasan hormon (misalnya, hormon pertumbuhan $[\mathrm{GH}]$, hormon tiroid $[\mathrm{TH}]$ ) dan 
peningkatan produksi dan sekresi beberapa faktor pertumbuhan. Faktor pertumbuhan yang berkaitan dengan latihan fisik termasuk insulin-like growth factor 1 (IGF1), hepatocyte growth factor (HGF), plateletderived growth factor (PDGF), vascular endothelial growth factor (VEGF), dan neuregulin-1 (NRG1). Rangsangan ini kemudian mengaktifkan banyak signal kaskade di jantung, mengarah ke proses seperti hipertrofi miosit jantung dan proliferasi, kontraktilitas miosit jantung, remodeling sarkomer, remodeling matriks ekstraselular (ECM), kelangsungan sel, angiogenesis, remodeling aktifitas listrik, dan adaptasi metabolik / mitokondria (Gambar 2). Peran faktor individu dan gen yang mengatur proses ini telah dinilai menggunakan model hewan. ${ }^{16}$

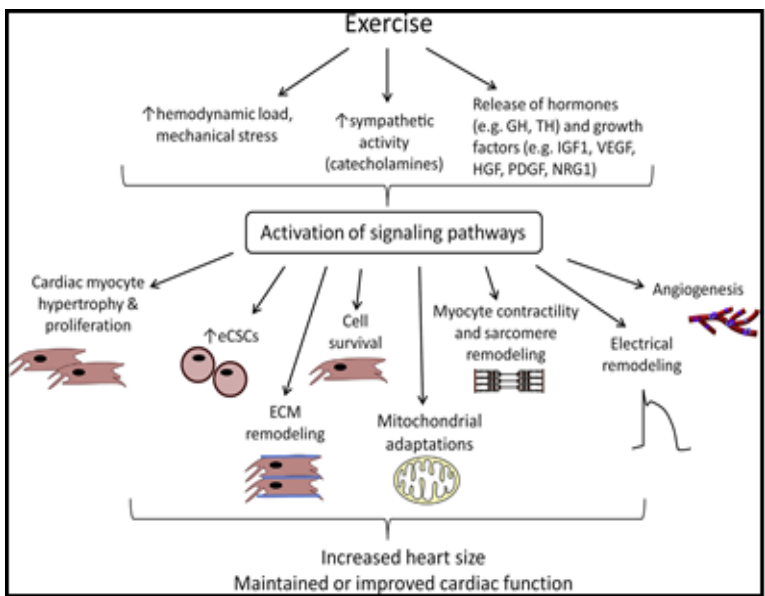

Gambar 2. Stimulus dan respon seluler terkait remodeling jantung ${ }^{16}$

Hipertrofi dan proliferasi miosit jantung

Hipertrofi miosit jantung berkontribusi dominan dalam pembesaran jantung karena sebagian besar miosit dewasa tidak dapat berproliferasi atau diperbaharui. Di sebagian besar studi dijelaskan proliferasi miokard atau pembaharuan jantung tidak secara khusus diperiksa. Namun, sekarang diketahui bahwa latihan fisik dapat menyebabkan proliferasi dan pembaharuan miosit dalam jumlah kecil. ${ }^{16}$

Peran jalur IGF1-phosphoinositide 3-kinase $(\mathrm{PI} \mathrm{KK})$ - fosoinideide - dependent protein kinase-1 (PDK1) - protein kinase B (Akt1) dalam memberikan kontribusi pada hipertrofi miosit telah diteliti karena jalur ini dikenal dapat mengendalikan sel dan ukuran organ. Pembentukan IGF1 jantung lebih tinggi pada pemain bola dengan hipertrofi fisiologis. Genetik model tikus telah digunakan untuk menilai peran insulin-like growth factor 1 receptor (IGF1R) - PI3KPDK1 - Akt1 sebagai mediasi latihan fisik yang menginduksi hipertrofi jantung (Lihat Gambar 3).Tikus dengan pengurangan aktivitas dari IGF1R, PI3K, PDK1 dan Akt1 menunjukkan respon hipertrofi yang tumpul terhadap latihan fisik. Terdapat beberapa kelas PI3K dan bentuk yang sejenis. PI3K (p110a) dan PI3K (p110b) merupakan isoform dominan yang mengatur hipertrofi fisiologis akibat latihan fisik. Regulator lain dari jalur ini, termasuk P21-activated kinase (PAK1; PDK2 potensial mengatur fosforilasi Akt pada miosit jantung) dan pro aktif Akt substrat $40 \mathrm{KDa}$ (PRAS40; protein pengikat yang menghambat target mamalia kompleks rapamycin 1 [MTORC1]) juga telah terbukti sebagai regulator penting hipertrofi jantung akibat latihan fisik (Lihat Gambar 3). ${ }^{17,18}$

Berbeda dengan respon tumpul hipertrofi akibat latihan fisik dengan penghapusan/pengurangan ekspresi jalur IGF1, peningkatan ekspresi jantung IGF1R atau Akt (melalui penghapusan PHLPP1) menyebabkan pembesaran respon hipertrofik terhadap latihan fisik. Ribosomal S6 kinase (S6K), yang berada di hilir jalur IGF1R-PI3K-PDK1-Akt1 dan penting untuk sintesis protein (lihat Gambar 3), tidak penting pada hipertrofi jantung akibat latihan fisik. Kompleksitas kaskade signal juga terlihat pada tikus IGF1R Knockout (KO). Meskipun Hipertrofi yang diinduksi latihan fisik adalah tumpul di tikus IGF1R KO, aktivasi Akt dipertahankan. sebuah mekanisme yang melibatkan AMP-activated protein kinase (AMPK) terlibat dalam respon hipertrofi yang tumpul. ${ }^{17,18}$

Tingkat sirkulasi $\mathrm{GH}$ dan faktor pertumbuhan termasuk PDGF, mengubah faktor pertumbuhan- $\beta$ (TGF $\beta$ ), VEGF, dan HGF, juga telah terbukti meningkat sebagai respon terhadap latihan fisik. Sebagai tambahan, tingkat sirkulasi NRG1 $\beta$ (termasuk faktor pertumbuhan epidermal) berkaitan dengan kebugaran pada individu sehat. Dari catatan, faktorfaktor pertumbuhan ini juga mengatur signal PI3K / Akt di jantung, dan peningkatan kadar $\mathrm{GH}$ meningkatkan IGF1 jantung (lihat Gambar 3). ${ }^{16,17}$

Axis hipotalamus-hipofisis-tiroid juga diaktifkan sebagai respons terhadap latihan fisik, dan level $\mathrm{TH}$ bisa bervariasi berdasarkan intensitas dan durasi latihan. TH muncul untuk mengatur gen jantung, 
termasuk myosin rantai berat, troponin jantung, sarkoplasmi/retikulum endoplasma Ca2+-ATPase (SERCA), dan reseptor TH (TRa1) ditunjukkan untuk berinteraksi dengan $\mathrm{PI} 3 \mathrm{~K}$ menginduksi sintesis protein pada miosit jantung. Dibandingkan dengan jalur IGF1PI3K-Akt, penelitian berbasis genetika dan molekuler yang dilakukan untuk menilai kontribusi langsung dari hormon-hormon tersebut dan faktor pertumbuhan (misalnya, VEGF, HGF, PDGF) dalam mengatur remodeling jantung akibat latihan fisik masih sedikit. Terdapat bukti yang menunjukkan bahwa beberapa faktor pertumbuhan ini penting mengatur fungsi jantung pada kondisi basal dan/atau sebagai respons terhadap beban fisiologis lainnya; contohnya, kehamilan. $^{17}$

Peningkatan eCS (proliferasi dan diferensiasi)

Di beberapa penyakit dan sebagai respon terhadap latihan fisik, jantung memiliki kapasitas untuk menghasilkan miosit baru baik dari endogen sel jantung / sel progenitor (eCSCs) atau miosit jantung yang sudah ada sebelumnya. Latihan fisik yang menginduksi hipertrofi (treadmill atau berenang) berkaitan dengan peningkatan jumlah eCSCs, dan beberapa kasus lainnya diferensiasi eCSCs menjadi miosit jantung dan kapiler saling terlibat. Waring dkk menjelaskan identifikasi miosit baru jantung berdasarkan dosis intensitas treadmill pada tikus selama 4 minggu. Grup dengan intensitas tinggi dikaitkan dengan pembesaran jantung akibat hipertrofi miosit jantung dan pembentukan miokard baru (kirakira 7\%), yang disebabkan oleh proliferasi dan diferensiasi eCSCs. Meningkatnya aktifitas simpatis (mengaktifkan $\beta 2$-adrenoreseptor [AR] pada eCSCs) dan IGF1, NRG1, dan HGF terlibat untuk mendorong proliferasi eCSC, sedangkan protein morfogenetik skeletal 10 dan TGF- $\beta 1$ dikeluarkan untuk merangsang diferensiasi ECSCs (Lihat Gambar 3). Namun, karena apoptosis dan / atau nekrosis tidak terjadi atau menurun pada hipertrofi fisiologis, dan eCSCs mungkin berada dalam lingkungan mikro yang terlindungi karena adanya faktor pertumbuhan yang dilepaskan setelah latihan fisik, ada kemungkinan jumlah yang meningkat dari eCSCs juga merupakan konsekuensi dari penurunan apoptosis/nekrosis. Mekanisme ini belum diketahui secara rinci. ${ }^{19}$
Kontraktilitas miosit jantung dan remodeling sarkomer

Respon terhadap latihan fisik, denyut jantung dan kontraktilitas jantung meningkat karena kebutuhan metabolik tubuh meningkat. Hal ini dipengaruhi oleh peningkatan kontraksi miosit jantung, yang dicapai dengan cara meningkatkan pengeluaran kalsium dari retikulum endoplasma yang berikatan dengan apparatus kontraktilitas dan remodeling sarkomer. ${ }^{16}$

Sebagai respon terhadap peningkatan beban latihan, miosit jantung juga akan mensintesis protein kontraktilitas baru dan merakit sarkomer baru. Myosin Heavy Chain protein (MHC), adalah protein kontraktil utama di jantung. Myocardium vertebrata memiliki dua isoform protein ini, $\alpha-\mathrm{MHC}$ dan $\beta-\mathrm{MHC}$. Yang terakhir ini dominan di hati manusia tapi yang pertama diperkirakan mendominasi jantung. Kedua protein ini memiliki peran penting dalam sifat kontraktil kardiomiosit. Perubahan pada salah satu protein $\alpha$ atau $\beta-\mathrm{MHC}$ dapat dikaitkan langsung dengan perubahan sifat kontraktilitas jantung. ${ }^{16,20}$

\section{Remodeling Matriks Ekstraseluler}

Pada penyakit jantung, pertumbuhan miosit jantung biasanya disertai dengan fibrosis jantung (sintesis ECM yang berlebihan; misalnya kolagen oleh fibroblas jantung), dan ini menyebabkan kekakuan jantung. Sebaliknya, regulasi ECM dalam merespon latihan fisik biasanya terjadi dengan cara yang terkoordinasi, memungkinkan kerangka kerja struktural untuk koordinasi proses mekanik, elektrik, dan kimiawi untuk memelihara kontraktilitas jantung normal. Dibandingkan dengan mekanisme molekuler untuk miosit jantung, mekanisme regulasi fibroblas masih belum diketahui. Namun, terdapat bukti yang menunjukkan bahwa pelepasan faktor dari miosit jantung berperan dalam regulasi respon ECM. Misalnya, signal IGF1-PI3K pada miosit jantung penting untuk proteksi dan pengendapan ECM normal melawan fibrosis jantung. ${ }^{21}$

\section{Cell Survival}

Berbeda dengan jantung yang sakit, yang berhubungan dengan peningkatan apoptosis, latihan fisik dikaitkan dengan tidak berubah atau berkurangnya apoptosis. Hal ini dikarenakan terjadinya peningkatan konsentrasi serum IGF-1. IGF- 
1 meningkatkan ekspresi Akt dan endothelial nitric oxide synthase (eNOS) yang memiliki efek antiapoptosis di miokardium. Werner et al (2008) meneliti pada tikus, bahwa berlari dapat meningkatkan ekspresi dan fungsi dari eNOS. Latihan fisik akan meningkatkan stabilisasi protein-telomere, mengurangi penuaan sel dan mencegah apoptosis. ${ }^{22}$

Adaptasi metabolik dan mitokondrial

Mitokondria memegang peranan penting dalam produksi energi. Jantung memperoleh energi sebagian besar berasal dari asam lemak (FAs), dengan glukosa dan laktat sebagai sumber tambahan. Penjagaan atau peningkatan metabolisme jantung, latihan fisik menyebabkan peningkatan oksidasi asam lemak dan glukosa, peningkatan biogenesis mitokondria, menginduksi jalur oksidasi asam lemak yang diatur oleh AMPK dan peroxisome proliferator activated receptor- $\alpha$ (PPAR $\alpha$ ), dan meningkatkan ekspresi gen lipogenik. PI3K terbukti penting untuk latihan yang diinduksi adaptasi mitokondria, tapi ini independen terhadap Akt dan PDK1. ${ }^{22}$

Aktifitas fisik menyebabkan peningkatan kepadatan volume mitokondria, yang dijelaskan oleh peningkatan jumlah dan juga pembesaran 550 dari kerapatan permukaan retikulum sarkoplasma (SR) per unit myofibril (rasio SR / myofibril) dan hiperplasia pada aparatus Golgi. Panjang sel pada umumnya ditemukan meningkat, mulai dari $5 \%$ sampai $20 \%$, kenaikan panjang ini bersifat reversibel. ${ }^{20}$
Remodeling elektrik Latihan kronis menyebabkan sinus bradikardi. Bradikardi secara luas dikaitkan dengan adaptasi sistem saraf otonom terhadap latihan kronis. Sinus nodal juga terkena dampak terhadap latihan fisik. Kanal ion yang berperan untuk aksi potensi sel nodal diantaranya, saluran $\mathrm{HCN}$ dan terutama HCN4 mendukung (If) yang mengendalikan aktivitas pacu jantung. Efek bradikardi akan latihan kronis akan kembali seperti semula setelah tikus tidak latihan selama 2 minggu dan ini terkait untuk peningkatan mRNA HCN4. ${ }^{20}$

\section{Angiogenesis dan Remodeling Vaskular}

Respon terhadap latihan fisik, proliferasi pembuluh darah dari pembuluh darah yang ada (yaitu, angiogenesis) dan bisa mengalami perubahan fenotipe (yaitu remodeling vaskular). Peningkatan angiogenesis dianggap sebagai respon untuk menjaga perfusi dan pasokan nutrisi yang adekuat untuk beberapa proses seperti hipertrofi miosit jantung. Ada dua jalur dasar untuk membentuk massa baru pada pembuluh darah fungsional, yaitu sprouting angiogenesis dan intussuceptive angiogenesis (nonsprouting). Dan pada saat bersamaan, inilah satusatunya proses yang efektif dalam peningkatan pertukaran antara darah dan jaringan. Sprouting angiogenesis terdiri dari ekspansi dan remodeling dari pembuluh darah yang sudah ada, cabang vaskular terhubung satu sama lain membentuk loop vaskular baru. Intususepsi memungkinkan peningkatan jumlah kapiler tanpa peningkatan jumlah sel endothelial. ${ }^{20}$ 


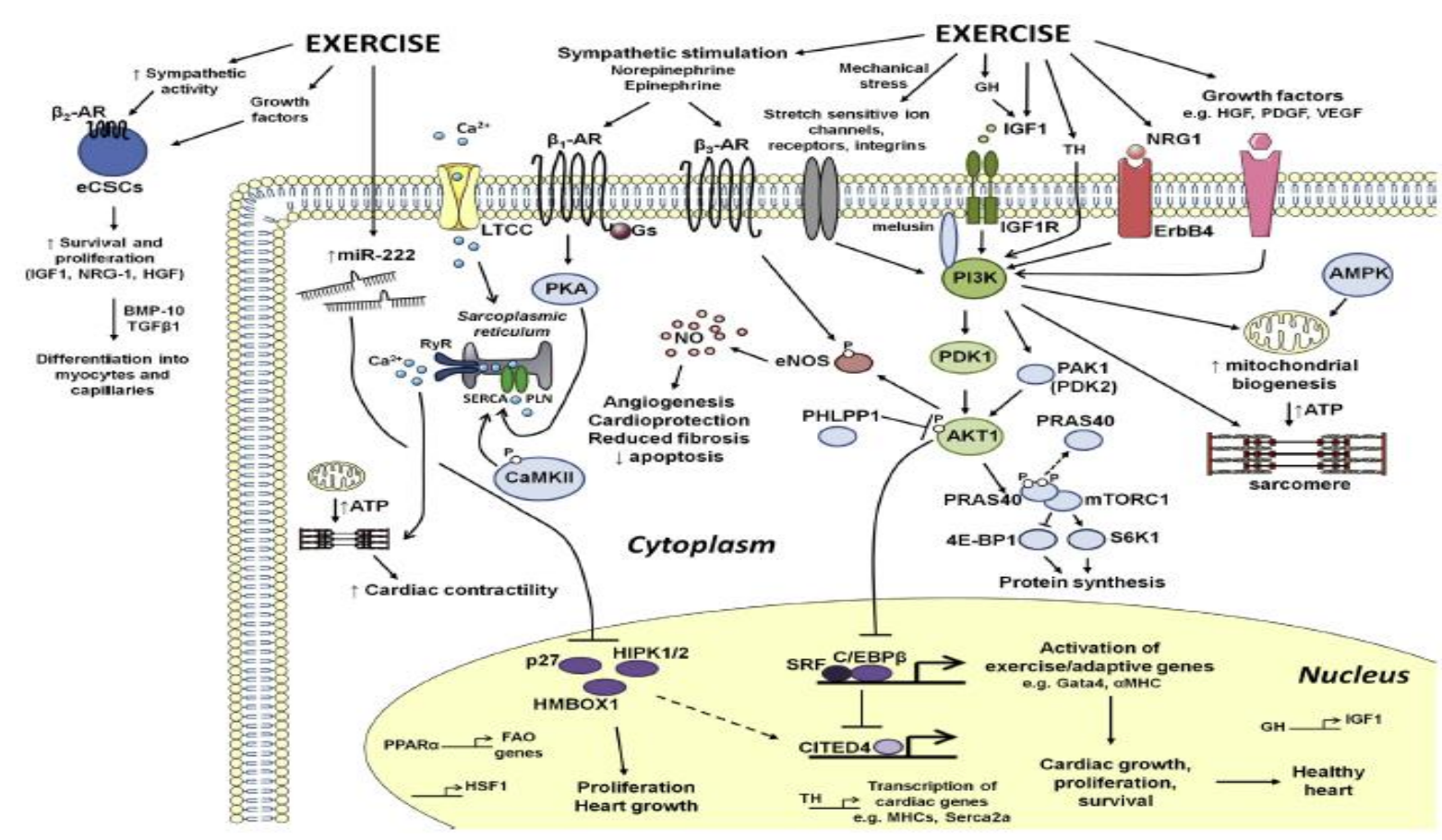

Gambar 3. Molekuler aspek dari remodeling jantung terhadap latihan fisik. ${ }^{16}$

Micrornas Pada Remodeling Jantung Yang Disebabkan Latihan Fisik

MicroRNAs (miRNAs) adalah non-protein yang mengkode RNAs kecil yang mengatur ekspresi gen dan berperan penting pada penyakit kardiovaskular. Ekspresi miR-29c meningkat terhadap respon latihan fisik dan berkorelasi terhadap penurunan 2 target yaitu: kolagen I dan III. Namun pemahaman tentang peran miRNA ini baru saja muncul. Saat ini miR-222 adalah satu-satunya miRNA yang diperlukan untuk pertumbuhan jantung yang disebabkan latihan fisik. miR-222 diregulasi di jantung pada tikus yang diberikan latihan renang atau lari, sama dengan di peredaran darah pasien dengan gagal jantung setelah melakukan latihan sepeda statis. ${ }^{16}$

Penghambatan miR-222 (menggunakan miRNA inhibitor) pada tikus mencegah peningkatan ukuran jantung yang disebabkan oleh latihan renang, menunjukkan bahwa miR-222 diperlukan untuk pertumbuhan jantung yang diinduksi latihan fisik. Secara mekanis, proliferasi miokard jantung dan regulasi gen target miR-222 (P27, inhibitor sel-cycle, dan homeobox termasuk protein 1, transcripsional repressor) dan Cited 4 juga terlibat. Enam minggu setelah ischemic injury, tikus transgenic miR-222 terlindungi dari remodeling jantung patologis. Jadi, miR-222 bisa menjadi target potensial terapeutik melawan stres jantung. miRNA juga disekresikan ke aliran darah sebagai respons terhadap latihan fisik (merujuk pada circulation miRNAs [c-miRNAs]). Yang menarik, pengaturan c-miRNA pada manusia dipengaruhi oleh jenis latihan, durasinya, dan intensitas latihan. ${ }^{4,16}$

\section{SIMPULAN}

Latihan fisik dilakukan secara terencana, terstruktur, berulang dan bertujuan meningkatkan atau menjaga kesehatan, sangat bermanfaat bagi individu yang sehat maupun yang memiliki resiko untuk terjadinya penyakit kardiovaskular (PKV). Proses awal remodeling jantung dipengaruhi oleh stimulus hemodinamik dari kelebihan beban transien, menyebabkan transkrip mRNA dan sintesis protein sehingga terjadi hipertrofi fisiologis.

Mekanisme molekuler remodeling jantung terkait latihan fisik terdiri dari hipertrofi miosit jantung dan perbaruan/proliferasi, peningkatan eCS, kontraktilitas miosit jantung dan remodeling sarkomer, remodeling matriks ekstraseluler, Cell Survival, adaptasi metabolik dan mitokondria, remodeling elektrik, angiogenesis dan remodeling vaskular. Selain itu juga terdapat peran microRNAs pada remodeling jantung yang disebabkan latihan fisik. 


\section{DAFTAR PUSTAKA}

1. Fletcher GF, Flipse TR, Safford RE. Exercise in health and cardiovascular disease. Dalam: Fuster V, Walsh R, Harrington RA, editor. Hurst's the heart. New York: McGraw-Hill Companies; 2011. hlm.2176-87.

2. Thompson PD, Baggish AL. Excersice and sports cardiology. Dalam: Zipes DP, Libby P, Bonow RO, Mann DL, Tomaselli GF, editor. Braunwald's heart disease: a textbook of cardiovascular medicine. Philadelphia: Elsevier Saunders; 2015. hlm.1771-8.

3. Eijsvogels TM, Molossi S, Lee DC, Emery MS, Thompson PD. Exercise at the extremes: the amount of exercise to reduce cardiovascular events. Journal of American College of Cardiology, 2016;67(3):316-29.

4. Fernandes T, Barauna VG, Negrao CE, Phillips MI, Oliveira EM. Aerobic exercise training promotes physiological cardiac remodeling. Am J Physiol Heart Circ Physiol. 2015;309(4):543-52.

5. Weiner RB, Baggish AL. Acute versus chronic exercise-induced left ventricular remodeling. Expert Review of Cardiovascular Therapy. 2014; 12(11):1243-6.

6. Azevedo PS, Polegato BF, Minicucci MF, Paiva SAR, Zornoff LAM. Cardiac remodeling: concepts, clinical impact, pathophysiological mechanism and pharmacologic treatment. Arq Bras Cardiol. 2016; 106(1):62-9.

7. Anand IS, Florea VG, Solomon SD, Konstam MA, Udelson JE. Noninvasive assessment of left ventricular remodeling: concepts, techniques and implications for clinical trials. J Card Fail. 2002; 8(6 Suppl):452-64.

8. Cavalcante PAM, Perilhao MS, da Silva AA, Serra AJ, Junior AF, Bocalini DS. Cardiac remodeling and physical exercise: a brief review about concepts and adaptations. International Journal of Sports Science. 2016; 6(2):52-61.

9. Pimenta L, Gama EF, Maifrino LBM, Souza RR. Effects of physical exercises on the ventricular myocardium. Journal of Brazilien Morphology Science. 2009; 26(2):113-17.

10. Cohn JN, Ferrari R, Sharpe N. Cardiac remodeling-concepts and clinical implications: consensus paper form an international forum on cardiac remodeling. Journal of the American College of Cardiology. 2000;35(3):569-82.

11. D'Andrea A, Formisano T, Riegler L, Scarafile R, America $\mathrm{R}$, Martone $\mathrm{F}$, et al. Acute and chronic response to exercise in athletes: the "supernormal heart". Dalam: Xiao J, editor. Exercise for cardiovascular disease prevention and treatment. Singapore: Springer; 2017.hlm.21-38.

12. Nadruz W. Myocardial remodeling in hypertension. Journal of Human Hypertension. 2015; 29(1):1-6.

13. Huang CY, Yang AL, Lin YM, Wu FN, Lin JA, Chan $Y S$, et al. Anit-apoptotic and pro-survival effects of exercise training on hypertensive hearts. Journal of Applied Physiology. 2012;112(5):883-91.

14. Kolwicz SC Jr, Purohit S, Tian R. Cardiac metabolism and its interactions with contraction, growth, and survival of cardiomiocytes. Journal of Circulation Research of American Heart Association. 2013;113(5):603-16.

15. Fernandes T, Soci UP, Oliveira EM. Eccentric and concentric cardiac hypertrophy induced by exercise training: microRNAs and molecular determinants. Brazilian Journal of Medical and Biological Research. 2011:44(9):836-47.

16. Bernardo BC, McMullen JR. Molecular aspects of exercise-induced cardiac remodeling. Cardiology Clinics. 2016;34(4):515-530.

17. Noh J, Wende AR, Olsen CD, Kim B, Bevins J, Zhu $\mathrm{Y}$, et al. Phosphoinositide dependent protein kinase 1 is required for exercise-induced cardiac hypertrophy but not the associated mitochondrial adaptations. Journal of Molecular and Cellular Cardiology. 2015; 89:297-305.

18. Kim J, Wende AR, Sena S, Theobald HA, Soto J, Sloan C, et al. Insulin-like growth factor I receptor signaling is required for exerciseinduced cardiac hypertrophy. Journal of Molecular Endocrinologr 2008; 22(11):2531-43.

19. Waring CD, Vicinanza C, Papalamprou A, Smith AJ, Purushothaman S, Goldspink DF, et al. The adult heart responds to increased workload with physiologic hypertrophy, cardiac stem cell activation, and new myocyte formation. European Heart Journal. 2014; 35(39):2722-31

20. Krzesiak A, Delpech N, Sebille S, Cognard C, Chatelier A. Structural, contractile and 
electrophysiological adaptations of cardiomyocytes

to chronic exercise. Dalam: Xiao J, editor. Exercise

for cardiovascular disease prevention and treatment; Singapore: Springer; 2017: 75-111.

21. Martin ML, Blaxall BC. Cardiac intercellular communication: are myocytes and fibroblasts fairweather friends? Journal of Cardiovascular Translational Research 2012; 5(6):768-82.

22. Werner C, Hanhoun M, Widmann T, Kazakov A, Semenov A, Pöss J, et al. Effects of physical exercise on myocardial telomereregulating proteins, survival pathways, and apoptosis. J Am Coll Cardiol. 2008; 52(6):470-82. 